\title{
Integration of Science Disciplinary Core Ideas and Environmental Themes through Constructivist Teaching Practices
}

\author{
Dorothy Holley ${ }^{1 *}$, Soonhye Park ${ }^{1}$ \\ ${ }^{1}$ North Carolina State University, USA
}

Received 26 April 2019 • Accepted 20 December 2019

\begin{abstract}
A descriptive, mixed methods study investigated learning outcomes and processes of integrating environmental education (EE) and science education (SE). Specifically, this study examined the impact of EE-based constructivist science teaching approach on students' science achievement scores, environmental self-efficacy, course completion rate, and perceptions of their learning experiences. Participants of the study $(\mathrm{N}=46)$ included students in a Physical Science course at one public high school in a southeastern state of the United States. Data sources included the students' final exam scores, standardized unit test scores, self-efficacy measurements, course completion data, and student written reflections. Data analysis indicated that students with an EEbased constructivist science teaching approach $(\mathrm{N}=23)$ performed higher on science achievement tests and developed statistically higher environmental self-efficacy than those in a traditional teaching classroom $(\mathrm{N}=23)$. More students passed the final exam $(96 \%)$ and the mean final exam score was four points higher (82) in EE-based constructivist teaching approach classes. Students who were in the EE-based constructivist science teaching approach classroom tended to perceive their learning experiences in more positive ways.
\end{abstract}

Keywords: constructivist, environmental education, mixed methods, science education, secondary education

\section{INTRODUCTION}

Science educators strive to achieve science literacy for all students with goals of increasing the number of students prepared for and entering STEM careers (Johnson, Peters-Burton, \& Moore, 2016). Many science reform efforts have touted the goal of increasing scientific literacy (DeBoer, 2000). According to the National Science Education Standards (NRC, 2000), and the Next Generation Science Standards (Bybee, 2014), scientific literacy is "the knowledge and understanding of scientific concepts and processes required for personal decision making, participating in civic and cultural affairs, and economic productivity" (NRC, 2000, p. 1). Scientifically literate citizens should be able to understand basic science related content and apply basic science practices to events they encounter in the news and in everyday life (Glaze, 2018). The trinity of science disciplines required for a basic high school diploma earth science, life science (biology), and physical science
- provides the backbone of scientific thinking, processes, and practices. Unlike other education goals, scientific literacy is not necessarily achievable by completing basic science courses in high school or even majoring in a science related field in college (Cobern, 1995; Glaze, 2018). Scientific literacy comes with understanding scientific epistemology that exemplifies scientific thinking, processes, and practices (Glaze, 2018). Becoming scientifically literate is a lifelong pursuit.

In order to support students in becoming scientifically literate, teachers teaching science courses in formal settings should focus on students' conceptual change. The National Research Council's How People Learn (2000) and How Students Learn (2005) posit constructivist instruction as a means to engage students with science content. To this end, Banilower, Cohen, Pasley, and Weiss (2010) focus on science instruction that engages students in learning and describes students as active processors of knowledge. Key findings of effective instruction include motivation, eliciting students' prior 


\section{Contribution to the literature}

This study found that using an EE-based constructivist science teaching approach

- Brought significant gains to knowledge and competency

- Significantly impacted dispositions such as self-efficacy.

- Increased student enthusiasm as noted in the student perceptions and interviews.

Using EE-based constructivist science teaching approaches are recommended to increase scientific literacy and increase the STEM workforce. While this was a small sample size, this study contributes to the literature investigating the impact of EE-based constructivist science teaching approach as an effective instructional strategy.

knowledge, intellectual engagement with relevant phenomena, use of evidence to critique claims, and sense-making (Banilower et al., 2010). Emphasizing constructivist teaching approaches is thought to promote conceptual change and subsequent science achievement among students (Lee \& Brown, 2018). Students' ability to think and problem solve depend on having a rich body of knowledge to organize, to build new knowledge, and to actively take control of their own learning (NRC, 2000).

One underutilized and understudied strategy for incorporating effective instruction is through integrating environmental themes into the science classroom. Environmental Education (EE) includes the awareness, knowledge, attitudes, skills, and motivations necessary to address environmental challenges (UNESCO, 1977). The ultimate goal of EE is environmental literacy, based on the mandate to educate future decision makers to be able to make quality decisions when asked (NAAEE, 2009). Acquiring environmental knowledge works to increase environmental literacy as well as science knowledge (Hungerford \& Volk, 1990). Best practices in achieving environmental literacy include making connections to students' everyday lives, bridging interdisciplinary goals and objectives, developing personal stake and responsibility, and being open to inquiry (Bodzin, Klein \& Weaver, 2010; Lieberman \& Hoody, 1998; NAAEE, 2009). These core aspects of EE can be understood through situated learning theory (Lave \& Wegner, 1991), in which learning is embedded with social and physical environments of students. Through social interactions with their peers, students talk about their learning activities, thereby developing knowledge (Lave \& Wegner, 1991). By providing an authentic learning experience in which to learn both science content knowledge (e.g., solution chemistry) and how to apply it (e.g., understanding causes of water pollution and how to mitigate them), EE has the potential to bring together the science content and inquiry-based skills necessary for building science literacy. Further, by using the environment as the integrating context for learning science, teachers may simultaneously equip students with the competencies (e.g., content knowledge and skills), dispositions (e.g., self-efficacy and pro-environmental attitudes), and motivations to tackle complex environmental issues (Ardoin, Bowers, Roth, \& Holthuis, 2018; Volk, Hungerford \& Tomera, 1984). Integrating EE themes into science classrooms engages students by providing opportunity to apply content knowledge at higher levels with relevant, action-oriented environmental issues. Although this approach is promising, use of EE in traditional settings is not mainstream, and few have investigated how EE might enhance relevancy and subsequent environmental self-efficacy among students. There is a gap in the literature concerning integrating an EE-based approach into science classrooms.

Critical components of effective instruction are constructivist teaching approaches (AAAS, 1993; Bybee, 2014). Science knowledge outcomes are connected to environmental knowledge or environmentally responsible decision-making skills (Hungerford \& Volk, 1990). Research suggests that merging constructivist teaching approaches with relevant EE themes to teach physical science would strengthen learning (Ardoin, Bowers, Roth, \& Holthuis, 2018; UNESCO, 1977). In this regard, this study aimed to examine the impact of integrating science disciplinary core ideas (Bybee, 2014) and $\mathrm{EE}$ themes with constructivist teaching approaches (hereafter called "EE-based constructivist science teaching approach") on students' science achievement and environmental self-efficacy. EE themes provided the mechanism to promote student engagement and improve scientific literacy. In addition, this study examined students' perceptions of their learning in order to better understand their metacognitive thought processes in active learning environments. Learning outcomes were analyzed using quantitative statistical analysis. Student perceptions were analyzed using qualitative research methods.

Research questions guiding this study were:

1. Do students with an EE-based constructivist science teaching approach perform better on science achievement tests than those with traditional science teaching?

2. Do students with an EE-based constructivist science teaching approach develop higher environmental self-efficacy than those with traditional science teaching? 
3. How do students perceive an EE-based constructivist science teaching approach?

By answering those questions, this study adds to the body of literature emerging in science education that encourages teaching science concepts around a central theme (Bodzin, Klein \& Weaver, 2010; Bybee, 2014).

\section{LITERATURE REVIEW}

\section{Scientific Literacy}

A main goal of science education has been developing scientific literacy for all students (DeBoer, 2000; Glaze, 2018; Roberts \& Bybee, 2014). Students who are scientifically literate have an understanding of key concepts and principles of science as well as a grasp of how science concepts integrate with personal and societal issues such as personal health, resource use and environmental quality (Roberts \& Bybee, 2014). As informed citizens, students who are scientifically literate are able to make informed decisions by applying scientific concepts, utilizing critical thinking and problem-solving skills (Roberts \& Bybee, 2014). A second goal of science education has been to increase the number of students prepared for and entering STEM careers (English, 2016; Johnson et al., 2016). Johnson et al. (2016) asserts that our national security and global economy is dependent on workers who are able to apply scientific concepts at high levels as well as utilize critical thinking and problem-solving skills.

Science educators should support students in building these competencies and developing scientific literacy through authentic learning opportunities. Student-centered classrooms can appropriately prepare all citizens and future voters and decision makers for personal and societal applications of science related issues (Dewey, 1938; Roberts \& Bybee, 2014). For example, Burrowes, (2003) found that students in his student-centered biology classes developed higher level thinking skills when compared to students in the traditional teacher-centered classes. Students described lessons in his classroom as being useful and they felt more motivated to pursue learning when the learning activities were related to their everyday life (Burrowes, 2003). Sadler (2011) describes motivating factors as science-based issues of morality, virtue and the physical world around them.

\section{Constructivism}

Best practices for teaching science to achieve scientific literacy for all students have for a long time been considered constructivist methodologies (Baviskar, Hartle \& Whitney, 2009; NRC, 1996). Current theoretical underpinnings of learning theories captured in science education methods courses include How People Learn (NRC, 2000), How Students learn (NRC, 2005) and Effective Science Instruction (Banilower et al., 2010).
Constructivist instructional strategies are learnercentered, allowing the learner the 'construct' knowledge (Vygotsky, 1978). Four criteria of constructivist teaching will be described as they impacted the teaching approach of the researcher.

One criterion of a constructivist teaching approach involves accessing prior knowledge (Banilower et al., 2010; Baviskar, Hartle, \& Whitney, 2009; NRC, 2005) because when new knowledge is incorporated into prior knowledge learning occurs (NRC, 2005). For example, in a study with preservice science teachers, Austin and Schmit (2009) used concept mapping to access understandings of content knowledge before developing pedagogies. New content understandings and methods were then incorporated into the preservice teachers learning experience. In another study, Banet and Ayuso (2003) elicited prior knowledge of their biology students in order to later create problem-solving lessons that were built on the students' misconceptions. Accessing students' prior knowledge was fundamental to the constructivist teaching approach of the lessons (Banet \& Ayuso, 2003).

A second criterion of a constructivist teaching approach is creating cognitive dissonance (Baviskar, Hartle \& Whitney, 2009). The misconceptions in Banet and Ayuso's (2009) lessons provided a level of cognitive disequilibrium for the learner. Problems based on the misconceptions were intentionally incorporated into lessons so that learners would work to make meaning of the dissonance. A tension between what the learner already knows and what is being taught allows the learner to incorporate new information accurately into the construct (Windschitl, 2002). The new knowledge forms with prior knowledge. Examples found in the literature include student collaboration and portfolio practices whereby students' comparisons create moments of dissonance with new and prior knowledge (Bodzin, Klein \& Weaver, 2010).

A third criterion of a constructivist teaching approach is applying knowledge with feedback (Baviskar, Hartle \& Whitney, 2009). Cooper (1995) describes the importance of student voice in thinking critically during the learning process. Application could also be in the form of debate, role play, and peer teaching (Bodzin, Klein \& Weaver, 2010). Collaborative learning happens when learners work together to solve a problem or discrepant event. For example, Burrowes (2003) compared two 100-student biology classes taught with different instructional approaches. In the constructivist taught class, students explained and elaborated on their learning to a peer, and later demonstrated greater learning as measured by exam grades. An important part of this criteria is the opportunity for the learner to check the validity of current constructs and to redefine constructs with the application of feedback. 
The final criterion is reflection on learning (Baviskar, Hartle \& Whitney, 2009; Bodzin, Klein \& Weaver, 2010; NRC, 2005). The National Academy of Sciences' report How People Learn expresses the importance of active learning with the term "metacognition." Metacognition refers to the students' ability to monitor their current levels of content mastery and predict how they might perform using the newly acquired knowledge in the future (NRC, 2000). Banilower et al. (2010) describe this pause in the learning cycle when students have the opportunity to actively process information internally as "sense-making." Other examples where reflection is used as a constructivist teaching strategy in the literature include journaling and self-assessments (Bodzin, Klein \& Weaver, 2010; NRC, 2000). Banet and Ayuso (2003) incorporated reflection on pre and post biology test scores as a way for students to evaluate their success in the course.

This study utilized constructivist teaching to facilitate student science learning in a secondary physical science class. Strategies to access prior knowledge, create cognitive dissonance, apply knowledge with feedback, and reflect on learning were incorporated into science lessons. The teaching approach utilized these criteria to promote a student-centered class and increase scientific literacy.

\section{Environmental Education (EE) Themes}

Constructivist learning theory aligns with tenants of situated learning (Lave \& Wenger, 1991). Situated within the context of classrooms, students engage in authentic learning experiences by applying knowledge to realworld scenarios. Students engage through social interaction with peers and with their community around them. Students engage with a focus on how they will interact and contribute to society as a whole. EE themes encourage student engagement because they are relevant to students' life experiences (Roberts \& Bybee, 2014).

Applying situated learning theory can achieve the goals of scientific literacy and increase student participation in the STEM pipeline through identity (Cooper, 2013; Greeno \& Engestrom, 2014) and motivation (Hogan, 2002). Lave and Wenger (1991) described the evolution of a student's identity in learning as a series of steps. The student begins by participating in the activity or situation in an authentic context using specific knowledge in order to participate (Cooper, 2013). Other students in the classroom are known as the community of learners or community of practice (Cooper, 2013, Lave \& Wenger, 1991). Participation in the community allows knowledge to be co-constructed and often invokes emotions of motivation and identity (Cooper, 2013). Students naturally want to develop the identity of full practitioners (Cooper, 2013). By developing identity and motivation, situated learning experiences increase citizenship skills (Hogan, 2002), civic responsibility and moral development (Cooper, 2013). Students engage in learning activities that are situated in specific contexts.

Environmental themes may provide relevant contexts promote critical thinking skills and increase scientific literacy (Lord, 1999; Plakitsi, 2010). The specific contexts of this study are EE themes. EE themes can include greenhouse gases, plastic pollution, recycling, water quality, renewable energy, green power, energy conservation and climate change (Bodzin, Klein \& Weaver, 2010; Plakitsi, 2010). Student-learners develop their identity as full practitioners and their motivation to engage as they construct knowledge in the context of EE themes. Incorporating EE themes into secondary physical science lessons is a way to provide relevancy and foster student engagement and motivation thereby increasing scientific literacy and access to the STEM pipeline.

\section{Environmental Self-Efficacy}

Because EE closely aligns with current understandings of how to build scientific literacy, it is not surprising that research supports EE as a useful tool for boosting science achievement. The relevance of EE has been shown to increase student engagement and enthusiasm (Lieberman, 2013), and raise test scores, even among those populations who traditionally underperform on these tests (Ardoin et al., 2018).

The literature suggests that utilizing Environmental themes provides many classroom benefits. EE has been found to be highly successful at meeting knowledge and competency outcomes (Wals, Brody, Dillon, \& Stevenson, 2014). Dispositions, such as self-efficacy, are also impacted by EE. (Ardoin et al., 2018; Volk et al., 1984). For example, Wang, Hong, Liu \& Lin (2018) studied the impact of argumentation and reflection of environmental issues on a cross section of 39 college students. Students' environmental self-efficacy increased and a noted shift from economic development to environmental protection and sustainability occurred (Wang et al., 2018). Other studies report that EE increases student engagement and enthusiasm as well as decreasing discipline and classroom management problems (Lieberman, 2013). Taken together, this research suggests that integrating EE into science classrooms may not only build scientific literacy, including environmental knowledge, affect, problem solving skills, and behavior (Stevenson, Peterson, Bondell, Mertig \& Moore, 2013; Hollweg et al., 2011), but also equip students with the awareness and skills needed in STEM jobs.

This study uses EE themes to provide relevant contexts through a constructivist teaching approach (Plakitsi, 2010). Evaluating environmental self-efficacy will provide valuable insights on the impact of student 
engagement with EE themes. Research is lacking in the degree to which EE is successful in current science reform, or standards-based learning.

Similar to constructivism, the focus of standardsbased learning is shifted to the learner (Wilcox, 2011) however the students' grade is comprised mainly of summative assessments, often standardized tests (Iamarino, 2014; Wilcox, 2011). Tretter and Jones (2003) compared high-school level, introductory physical science classes taught using traditional instruction (low levels of inquiry) and inquiry instruction by the same teacher. Standardized test scores were not significantly impacted by the constructivist inquiry methods, but other benefits were noted such as student participation and classroom grades. Some studies in the literature found students taught with constructivist methods did not perform better on standardized tests (Hogan, 2002). For example, Hogan (2002) found that service learning (an example of situated learning) did not improve test performance. Choi and Hannafin (1995) surmised that in developing memorization strategies for standardized tests, students actively decontextualize knowledge such that "traditional testing strategies are often counterproductive for the solving of real-world problems" (Choi \& Hannafin, 1995, p. 63). Some studies found EE students performed better on standardized tests in science and math (Lieberman, 2013). A gap in the literature is the influence of EE themes in providing relevancy to constructivist teaching approach in improving science literacy and access to the STEM pipeline. More studies are needed to better understand the impact of EE themes on student performance and environmental self-efficacy.

\section{METHODS}

A descriptive, mixed methods study (Creswell, 2013) was conducted to investigate the impact of integrating science disciplinary core ideas (Bybee, 2014) and EE themes with constructivist teaching approaches (i.e., EEBased constructivist science teaching approach) on students' science achievement and environmental selfefficacy. Differences in student outcomes between EEbased constructivist science teaching approaches and traditional science teaching approaches were explored with a quasi-experimental design (Patton, 2015).

\section{Participants}

Participants of the study were $4610^{\text {th }}$ grade students who enrolled in two physical science sections taught by two science teachers at Central High School (pseudonym) during the spring semester. Central High School is one of 10 public high schools in a southeastern state of the United States. According to the county's web site, $43 \%$ of the public-school students tested at least proficient in math and $48 \%$ of students tested at least proficient in reading. Central High School has a student population of 1502, with $43 \%$ minority and $30 \%$ receiving free or reduced lunch (US News, 2017).

At Central High school, students typically take physical science during their sophomore year of high school, meeting one of the three required science credits for high school graduation. Students who are more focused on college preparatory coursework often opt out of taking physical science and take chemistry. Students in the study were randomly assigned to a physical science teacher. One of the physical science teachers was the researcher, the first author of this study. Both teachers in the study have been teaching various science subjects for more than 20 years, neither teacher has taught physical science for more than 4 years. The physical science content was taught using a traditional teaching approach by one teacher and using an EE-based constructivist science teaching approach by the researcher. Each teacher had the same course standards for teaching physical science guided by the state standards and all students were given the same unit tests and final exam. Teachers participated in a biweekly physical science professional learning community (PLC) for collaboration and pacing.

The spring semester lasted for 86 days. There were 80 days designated by the school for instruction and 6 days designated for administering final exams at the end of the semester. The 80 instructional days included days the students did not actually attend class due to inclement weather (snow), ACT testing, early release days for teachers' professional development, and a "virtual day" where students did not attend school but had assignments to complete at home and submit online to teachers.

\section{Intervention}

\section{Traditional science teaching approach (Control group)}

The physical science teacher using the traditional teaching approach has a bachelor's degree in zoology and a master's degree in science education. She has twenty-eight years of teaching experience. The semester of the research study was the teacher's fifth semester teaching physical science at the high school.

Traditional science approach to teaching physical science was taught in the third block of the school's four block day. Data from 23 students were used in the study. Data from four of the original 27 students were unusable because the students were no longer enrolled in the physical science class and did not complete the final environmental self-efficacy survey. Students sat in one of three rows of desks facing the whiteboard in the classroom. Students began the day by completing warm up problems on their paper that were projected on a whiteboard at the front of the room to review the previous days' content. Students took notes from PowerPoint slides during teacher instruction to learn 
Table 1. Summary of Course Units and Assessments for Teaching Approach $(\mathrm{N}=46)$

\begin{tabular}{lcccc}
\hline & \multicolumn{2}{c}{ Number of days spent on Unit } & \multicolumn{2}{c}{ Unit test given on Unit } \\
\hline Unit & $\begin{array}{c}\text { Traditional } \\
(\mathrm{n}=23)\end{array}$ & $\begin{array}{c}\text { EE-based constructivist } \\
(\mathrm{n}=23)\end{array}$ & $\begin{array}{c}\text { Traditional } \\
(\mathrm{n}=23)\end{array}$ & $\begin{array}{c}\text { EE-based constructivist } \\
(\mathrm{n}=23)\end{array}$ \\
\hline 1: Matter & 11 & 11 & $\sqrt{ }$ & $\sqrt{ }$ \\
2: Atoms \& Periodic Table & 7 & 7 & $\sqrt{ }$ & $\sqrt{ }$ \\
3: Chemical Bonding & 10 & 8 & $\sqrt{ }$ & $\sqrt{ }$ \\
4: Chemical Reactions & 8 & 7 & & $\sqrt{ }$ \\
5: Solution Chemistry & 4 & 4 & $\sqrt{ }$ \\
6: Nuclear Chemistry & 3 & 5 & $\sqrt{ }$ & $\sqrt{ }$ \\
7: Motion & 7 & 7 & 7 & $\sqrt{ }$ \\
8: Force \& Newton's Laws & 8 & 7 & $\sqrt{ }$ \\
9: Energy & 9 & 10 & 7 & $\sqrt{ }$ \\
10: Electricity \& Magnetism & 3 & 4 & $\sqrt{ }$ \\
11: Waves & 1 & 3 & $\sqrt{ }$ \\
Final Exam Review & 10 & 9 & & $\sqrt{ }$ \\
\hline
\end{tabular}

Note: Length of the semester was 86 days. The final exam was given during the last six days of the semester

Table 2. Physical Science Concepts, EE themes and Constructivist Best Practices

\begin{tabular}{ccc}
\hline Physical Science Concepts & EE Themes & Research Supported Best Practices \\
\hline Density & Greenhouse gases & Collaboration \\
Chemical formulas & Plastic pollution & Role play \\
Chemical equations & Recycling & Concept mapping \\
Solutions & Water quality & Journaling \\
Nuclear Chemistry & Renewable energy & Peer teaching \\
Power & Green power & Portfolios \\
Energy & Energy conservation & Debate \\
Waves & Climate change & Relevancy \\
\hline
\end{tabular}

new content. Students then completed worksheets to practice newly learned skills and concepts. Chapter outlines were assigned for each unit and guided students through textbook readings as a way to both review and reinforce content knowledge. A quiz and study guide were given during each unit of study. The teacher-led online platform Edmodo was used to communicate for students who were absent. County made standardized unit test data are missing for five of the 11 units of the traditional science teaching approach class. Table 1 summarizes the instructional units and assessment availability for each teaching approach.

\section{EE based constructivist science teaching approach (Experimental group)}

The researcher has a bachelor's degree in chemistry and a master's degree in environmental education. The semester of the research study was her second semester teaching physical science at the high school.

EE based constructivist science teaching approach was taught first block in the school's four block day. Data from 23 students were used in the study. Data from seven of the original 30 students were unusable because the students were no longer enrolled in the physical science class and did not complete the final environmental self-efficacy survey. Students sat at one of eight large tables in the classroom. Lab benches on the perimeter of the room were used for lab investigations approximately once each week. Chapter outlines assigned for each unit were due at the beginning of the unit to access students' prior knowledge. "Warm Up" questions assigned at the beginning of class each day also accessed prior knowledge or reviewed previous content. Teacher instruction utilized constructivist practices and emphasis was placed on student collaboration with tablemates. Students were routinely asked to assimilate new information into recent units of study, which often incorporated EE themes. For example, students researched and debated renewable energy resources to increase the relevancy of the study of the physical science concept power. Science concepts taught with the connection to EE themes and constructivist practices are given in Table 2.

Students taught using EE based constructivist science teaching approach also completed activities to apply knowledge with feedback from the researcher and tablemates. At least one quiz was given during the unit to provide more formal feedback on student performance. Science careers were routinely discussed in practical application and the researcher secured an architecture internship for one student with a community partner. The researcher's teacher-website contained online information and resources and was available for students as needed. At the end of each unit students completed a notebook portfolio of their work and wrote a reflection of their learning in student journals. 


\section{Data collection}

The parental consent letter was distributed and collected after Institutional Review Board (IRB) approval. Only data for students with completed parental consent letters on file were used for the study. The science teacher in the traditional physical science class was trained by the principal researcher in administering the on-line self-efficacy assessment. Confidentiality was honored for each student and student names were not printed in any of the researcher's manuscripts.

Main data sources for this study included student scores on unit tests and a final test, student responses to the environmental self-efficacy survey collected from 46 students in both control and experimental classrooms.

\section{Unit tests}

Students completed unit tests at the end of each unit of study in the physical science course. Each unit lasted between two and eleven days. The grade on the unit test was collected from the classroom teacher. Due to time constraints, the teacher of the traditional science teaching approach class chose not to give the county made standardized unit tests for five of the 11 units. Data from the unit tests of EEbased constructivist science teaching approach classes were removed from the study and the six units were averaged for comparison.

\section{Final test}

The final test was a standardized exam created by the state department.

\section{Environmental self-efficacy survey}

Students took the online self-efficacy survey (Szczytko, Stevenson, Peterson, Nietfeld, \& Strnad, 2018) at the beginning of the semester (February, 2018) and at the end of the semester (June, 2018). A total of 57 students took the self-efficacy survey at the beginning of the semester. The survey took approximately ten minutes to complete. Students self-reported gender and physical science teacher. No other demographic data was collected.

\section{Student journals}

To understand students' perceptions of the EE based constructivist science teaching approach, students in the experimental classroom were asked to write a reflection in their Student Journals at the completion of each unit, either before or after taking the unit test. Journal prompts were: What did you learn in this unit? What would you like to improve? Students were immediately able to view their online test results and reflect on the questions that they missed.

\section{Student interviews}

Among the students in the EE based constructivist science teaching approach, five students were selected and interviewed by the researcher about their strong opinions expressed in journal reflections. Semi structured interviews asked the students to clarify the themes of instruction, collaboration and relevancy that surfaced during the qualitative analysis.

\section{Field notes}

In addition, the researcher kept field notes in which she recorded PLC notes, class antidotes, attendance trends, and other observations pertinent to the study.

\section{Measures}

Instrument for measuring academic performance. To measure students' science achievement in the two physical science classes, a unit test average and a final exam were used. The local school district developed standardized performance assessments for each of the eleven units in the physical science course. Each of the 11 unit tests consisted of 20-30 multiple choice questions administered through an online testing website during class. For scoring the unit test, the number of correct answers for each test was converted to a percentage of 100 score and recorded by the teacher. Both physical science teachers used the unit test grade as an assessment grade. Test grades were weighted as $50 \%$ of the student's grade for the marking term. The unit test average represents the average percentage of 100 score of the six unit tests that were given by both the experimental and the control groups.

The state's Department of Public Instruction (DPI) developed a standardized performance assessment final exam. It consisted of 45 multiple choice questions and was also administered through an online testing website. For scoring the final exam, the number of correct answers was converted to a raw score and curved as determined by the county local education authority (LEA). The reported exam grade is expressed as a percentage of 100 . Exam grades were weighted as $20 \%$ of the student's final grade and each marking period contributing $40 \%$ of the student's final grade for the class, as mandated by county policy.

Instrument for measuring environmental self-ef ficacy. Student environmental self-efficacy was measured using a 12 question "hope" scale which asked students about their current beliefs (see Appendix A). Statements were measured using a 5-point Likerttype scale ranging from "strongly disagree" (1 point) "disagree" (2 points), "neutral" (3 points), "agree" (4 points), and "strongly agree" (5 points) (Szczytko et al., 2018). Scores ranged from 12 to 60; a higher score indicated a higher level of cognitive belief in their own self-efficacy in affecting the environment. 


\section{Data Analysis}

Student data in the study were grouped according to classroom teacher. Of the 57 students who completed the initial environmental self-efficacy survey, 46 students' data were used for self-efficacy data analysis. Twentythree students had been randomly assigned to the traditional teaching method class and 23 had been assigned to the EE-based constructivist science teaching method class. Eleven of the original 57 students were unusable because the student was no longer enrolled in the physical science class and did not complete the final environmental self-efficacy survey. Using a cross sectional design between groups, unit test scores and environmental self-efficacy measurements were compared of physical science students $(\mathrm{N}=43)$ in the study.

To answer the first research question, "Do students with an EE-based constructivist science teaching approach perform better on science achievement tests than those with traditional science teaching?," statemandated standardized final exams and county-made standardized unit test averages assessment data were analyzed and compared using a t-test between the two classes for each test using STATA software. Data from 23 students in each group $(\mathrm{N}=46)$ were used in the study.

To answer the second research question, "Do students with an EE-based constructivist science teaching approach develop higher environmental selfefficacy than their counterparts?" changes in selfefficacy scale data were analyzed and compared between classes where EE-based constructivist science teaching approach was used and classes where traditional science teaching was used using a t-test using STATA software. The change in self-efficacy was the difference in the initial environmental self-efficacy score, taken in February, and the final environmental selfefficacy score, taken in June. Data from 23 students in each group $(\mathrm{N}=46)$ were used in the study.

To answer the third research question, "How do students perceive an EE-based constructivist science teaching approach?" student reflections of open-ended experience questions were considered. Through inductive coding (Creswell, 2013), codes were developed for student comments written in the journals. Students were asked to reflect on their learning for each unit and how they perceived things that impacted their learning. The codes were lumped into categories and themes emerged (Wolcott, 1994). In the first cycle of coding, the reflections were compiled and organized by topics in the data. The researcher read through teacher and student journals and developed codes using holistic, descriptive strategies (Creswell, 2013). Another researcher in the teaching field compared codes and inter-coder agreement was established. Eight codes were reported and then collapsed into three distinct themes. Five interviews were conducted to elaborate on perceptions of the class and to clarify themes found in the journals. Interviews were transcribed. The researcher read through the transcribed texts and developed codes that described how they perceived the course content, their classmates, their teacher, and how they performed. New descriptive data were added to the three existing themes. In the second cycle of coding data from the journals and interviews were aggregated to provide rich, think data as well as establish emergent themes and patterns (Wolcott, 1994). Naturalistic generalizations (Creswell, 2013) were developed which answered the research question, "How do students perceive an EE-based constructivist science teaching approach?"

\section{RESULTS}

\section{Impact of an EE-based Constructivist Science Teaching Approach on Students' Science Achievement}

Student science achievement scores are reported in Table 3. The range of unit test scores was 22 to 100 out of 100 possible points for each test. Although the curriculum consisted of 11 wunits, only six unit tests were given in the class with the traditional science teaching approach as noted in Table 3 . The teacher chose not to give unit assessments for Units 5,6,9,10,11. The class with the EE-based constructivist science teaching approach did take the unit assessments for all 11 units. The average unit test score of all students in both classes for the six comparable unit tests was 65 points out of 100 possible points. The range in final exam scores in both classes was 50 to 99 out of 100 possible points. Students scored between 17 and 100 points out of a possible 100point scale on the standardized unit tests. Aggregate mean scores are shown in Table 3. Traditional teaching approach $(n=23)$ students' mean scores of unit tests taken across the semester ranged from 44 to 88 . The aggregate mean unit test grade for all traditionally taught students was 62 as shown in Table 3. EE-based constructivist science teaching approach $(n=23)$ students' mean scores of unit tests taken across the semester ranged from 34 to 92 . The aggregate mean unit test grade for all students taught with an EE-based constructivist science teaching approach was 66 as shown in Table 3 . The range of mean unit test scores for all physical science students $(\mathrm{N}=46)$ was 43 to 73 with the mean being 64 points.

To answer the first research question, "Do students with an EE-based constructivist science teaching approach perform better on science achievement tests than those with traditional science teaching?," standardized final exam assessment data were analyzed and compared between classes where EE-based science teaching approach was used and classes where traditional science teaching was used. A t-test was used to compare mean exam scores for the two different teaching approaches using STATA software and the 
Table 3. Comparison of Teaching Approach on Six Unit Test and Mean Unit Test Scores

\begin{tabular}{|c|c|c|c|c|c|}
\hline & \multicolumn{2}{|c|}{ EE-based constructivist $(n=23)$} & \multicolumn{2}{|c|}{ Traditional $(n=23)$} & \multirow[b]{2}{*}{$t$-test } \\
\hline & $\mathrm{M}$ & SD & M & SD & \\
\hline Unit 1 Test Mean & 71.87 & 15.07 & 72.70 & 13.06 & -0.20 \\
\hline Unit 2 Test Mean & 59.35 & 18.10 & 60.78 & 17.64 & -0.27 \\
\hline Unit 3 Test Mean & 60.26 & 23.27 & 67.83 & 20.01 & -1.18 \\
\hline Unit 4 Test Mean & 67.09 & 23.16 & 66.70 & 22.81 & 0.06 \\
\hline Unit 7 Test Mean & 69.79 & 18.23 & 62.43 & 34.64 & 0.90 \\
\hline Unit 8 Test Mean & 69.78 & 16.12 & 42.61 & 32.87 & $3.56^{* *}$ \\
\hline Mean unit test score & 66.36 & 15.63 & 62.17 & 19.40 & 0.80 \\
\hline
\end{tabular}

** $\mathrm{p}<.01$.

Note: $\mathrm{M}=$ Mean SD = Standard Deviation.

Note: Unit test scores and Final Exam scores are out of 100 possible points.

Table 4. Comparison of Teaching Approach on Final Exam Scores

\begin{tabular}{lcccccc}
\hline Teaching Approach & $\mathrm{n}$ & Mean & SD & t-cal & Df & $p$ \\
\hline EE-based constructivist & 23 & 84.30 & 10.44 & 1.81 & 44 & \\
Traditional & 23 & 78.17 & 12.42 & & & \\
\hline
\end{tabular}
${ }^{*} \mathrm{p}<.05$.

Table 5. Student Environmental Self-efficacy $(\mathrm{N}=46)$

\begin{tabular}{lcc}
\hline & Traditional $(\mathrm{n}=23)$ & EE-based constructivist $(\mathrm{n}=23)$ \\
\hline Beginning Mean Environmental Self-Efficacy Score & 37.30 & 37.82 \\
End Mean Environmental Self-Efficacy Score & 36.78 & 39.74 \\
Change in Environmental Self-Efficacy & -.52 & 1.92 \\
\hline
\end{tabular}

Note: Environmental Self-efficacy scores are out of 60 possible points. Change in Environmental Self-efficacy is the difference in the beginning and ending scores

results are shown in Table 4 . Students in the EE based constructivist science teaching method performed significantly higher than students in the traditional teaching method class on the standardized final exam $(\mathrm{t}(41)=1.81 ; \mathrm{p}<.04)$.

To further answer the first research question, "Do students with an EE-based constructivist teaching approach perform better on science achievement tests than those with traditional science teaching?" a series of t-tests were also run to compare mean county-made standardized unit test scores of six unit tests and the mean unit test score for the two different teaching approaches using STATA software and the results are shown in Table 3. The traditional science teaching approach mean unit test score was 62.17 and the EEbased constructivist science teaching approach mean final unit test score was 66.36. The difference between the two approaches yielded statistically significant results only for the Unit 8 Mean $(t(44)=3.56$; $\mathrm{p}<.0009)$. This finding is discussed further below.

\section{Impact of an EE-based Constructivist Science} Teaching Approach on Students' Environmental Selfefficacy

The range of self-efficacy scores was 12 to 53 out of 60 possible points for all students in the study. The mean self-efficacy score was 38.6 out of a possible 60 points at the beginning of the course and 38.7 at the end of the course. Aggregate mean scores are shown in Table 5.
Over the course of the semester, the change in en vironmental self-efficacy for traditionally taught students $(n=23)$ was -.52 and the change in environmental self-efficacy for students taught with the EE-based constructivist science teaching approach $(n=23)$ was 1.92 as measured with the environmental self-efficacy scale and as shown in Table 5.

To answer the second research question, "Do students with an EE-based constructivist science teaching approach develop higher environmental selfefficacy than their counterparts?," self-efficacy scale data were analyzed and compared between classes where EEbased constructivist science teaching approach was used and classes where traditional science teaching was used. A t-test was used to compare the difference in environmental self-efficacy scores over the course of the semester for the two different teaching approaches using STATA software. The results are shown in Table 6.

At the beginning of the course, the difference in environmental self-efficacy scores between the two groups was not statistically significant. The traditional science teaching approach average self-efficacy score was 37.30 and the EE-based constructivist science teaching approach average self-efficacy score was 37.82. At the end of the course, the traditional science teaching approach average environmental self-efficacy score was 36.78 and the EE-based constructivist science teaching approach average environmental self-efficacy score was 39.74. The traditional science teaching approach showed 
Table 6. Comparison of Teaching Approach on Change in Environmental Self-Efficacy

\begin{tabular}{lccccc}
\hline Teaching Approach & $\mathrm{n}$ & Mean & SD & z-cal & $\mathrm{p}$ \\
\hline EE-based constructivist & 23 & 1.91 & 1 & 8.26 & $.00^{* * *}$ \\
Traditional & 23 & -.52 & 1 & & \\
\hline
\end{tabular}

Traditional

$-.52$

*** $p<.001$.

Table 7. Student reflections during an EE-based constructivist science teaching approach physical science course

\begin{tabular}{|c|c|c|}
\hline Theme & Perception & Journal or interview example \\
\hline \multirow[t]{3}{*}{ Instruction } & General thoughts on science & $\begin{array}{l}\text { I'm not good at science, it seems hard. } \\
\text { This subject is easy, everything is going good }\end{array}$ \\
\hline & Perception about the class & $\begin{array}{l}\text { Too much work on virtual day, other classes didn't assign as much } \\
\text { work. }\end{array}$ \\
\hline & Perception about a pedagogy & $\begin{array}{l}\text { The labs are fun, but I wish we didn't have to write a discussion. } \\
\text { I like doing things hands on. }\end{array}$ \\
\hline \multirow[t]{3}{*}{ Collaboration } & Group Perceptions & $\begin{array}{l}\text { I liked how we worked together on some problems. } \\
\text { I miss my old tablemates in this unit } \\
\text { Unit } 10 \text { was harder when our teacher wasn't there. }\end{array}$ \\
\hline & Personal Perceptions & $\begin{array}{l}\text { I'm getting better at my notebooks; I should turn my outlines in on } \\
\text { time }\end{array}$ \\
\hline & $\begin{array}{l}\text { Perception about Virtual day } \\
\text { collaboration }\end{array}$ & $\begin{array}{l}\text { Virtual day wasn't good for me because I wasn't able to talk to my } \\
\text { tablemates. }\end{array}$ \\
\hline \multirow[t]{2}{*}{ Relevancy } & Perception about environment & Energy is important. I didn't know you could store wind. \\
\hline & Virtual day responsibility & $\begin{array}{l}\text { I didn't do as well on the test after virtual day. If we have another one } \\
\text { (virtual day) we shouldn't be tested on what we are supposed to learn. }\end{array}$ \\
\hline
\end{tabular}

a slight decrease in self-efficacy. The pre-test to post-test difference in environmental self-efficacy scores between the two approaches was statistically significant, $(\mathrm{z}=8.26$; $\mathrm{p}<.0000$ ) causing us to reject the null hypothesis based on the z-test analysis and to accept the alternate hypothesis that students in the EE-based constructivist science teaching approach do develop higher environmental self-efficacy.

\section{Student Perceptions of EE-based Constructivist Science Teaching Approach}

Students in the study wrote in student journals using prompts to reflect on their learning during the unit. Inductive coding (Creswell, 2013) was used to develop codes based on perceptions. Codes were grouped into themes as shown in Table 7. Student Engagement rubrics were used to describe science skills during the semesterlong course. Rubric results were shared with students in the EE-based teaching approach. A final journal reflection was made to record big ideas about the course and how students saw themselves as learners. Student interviews provided more clarification on student comments made in the journals or noted in the rubrics.

To answer the third research question, "How do students perceive an EE-based constructivist science teaching approach?" student reflections of open-ended experience questions were considered. Students wrote about things that impacted them - like the course or types of activities - or what they thought about the things that impacted them - like whether they liked or didn't like the activities. Some students chose to make suggestions for the course such as the teacher allowing them to listen to music or having a google classroom. The suggestions did not indicate positive nor negative perceptions. Students were generally positive about their perceptions. Students who had negative perceptions, "I didn't do well on this test," also tended to add hopeful perceptions, "I need to study more."

When students in the EE-based constructivist science teaching approach class were given an opportunity to reflect on positive and negative aspects of a specific day (a day where students were not able to attend school because of water line maintenance and students were required to work from home), 50\% of students' comments were negative. Since students were asked to give both types of comments, a balanced number was expected. However, only $38 \%$ of students' comments were positive and $13 \%$ of students in the EE-based constructivist science teaching approach class expressed indifferent opinions to the online virtual day. Data analysis of student reflections revealed the following three themes about non-online students' perceptions of virtual learning experiences.

\section{Instruction}

Students described having too much work on virtual day, not liking the online platform and enjoying doing science in their pajamas. Suggestions were made for instruction to be similar to other classes, "we should take pictures" or "I liked doing a worksheet in history."

\section{Collaboration}

Students wrote about missing the opportunity to work with lab partners and do labs, doing problems with 
tablemates, not being able to get help from their teacher (although the teacher was online and available during normal school day hours). One student commented "Virtual day wasn't good for me because I wasn't able to speak with anyone about the problem I was having like I can in class."

\section{Relevancy}

Some participants elaborated on the choice of subject matter on virtual day. "I didn't do as well on the test when I didn't do the study guide with my partner, I don't think we should be responsible for work we were supposed to do by ourselves."

\section{DISCUSSION}

Based on student achievement scores, environmental self-efficacy scores, student performance data and reflections, three themes emerged from this study. First, similar to Ardoin et al. (2018), this study found that EEbased constructivist science teaching approaches brought gains to knowledge and competency outcomes. Students in the EE based constructivist science teaching approach scored significantly higher on the standardized final exam, one measure of student content knowledge. With the exception of Unit 8, other standardized test data were unit tests developed by a different agency - with perhaps a different level of thinking skills - did not yield significant results. Unit 8 was the final unit of comparison between the two approaches. Tretter and Jones (2003) found that students taught with an inquiry approach had higher attendance and class participation rates. Further research might compare student attendance patterns of the two instructional approaches. Hogan (2002) found that contextualized learning in meaningful activity does not necessarily improve standardized test performance. Choi and Hannafin (1995) reported that standardized testing strategies promote memorization - and thus the decontextualization - of knowledge. So while it is important to note that EE constructivist science teaching may or may not have improved student science achievement as measured by standardized tests, it is also important to note that EE constructivist science teaching did not harm any student science achievement as measured by stan dardized tests. Students did not do worse than their traditionally taught counterparts. More research is needed to better evaluate the impact of an EEbased constructivist science teaching approach on student science achievement.

Second, similar to Ardoin et al. (2018) and Volk et al. (1984) this study found that EE-based constructivist teaching approaches significantly impacted dispositions such as environmental self-efficacy scores. Students in this study developed a higher environmental selfefficacy as measured by the "hope" scale. Reviews including Lieberman (2013), Stevenson et al. (2013) and
Hollweg et al. (2011) reported that cooperation with other students builds problem solving skills, decreases behavior issues and increases student engagement. More research, including dispositions not observed in this study, is needed to better understand the mechanism of how student self-efficacy might be impacted in science classrooms.

Third, similar to Lieberman (2013) this study found that that EE-based constructivist teaching approaches tended to increase student enthusiasm as noted in the student perceptions and interviews.Student perceptions of the thematic approach of this study are consistent with what Österlind (2005) described as relevant to student learning. Students commented on things that impacted their own learning, they were generally positive about the relevancy of their work, the ability to collaborate with their peers, and the methods of instruction.

Finally, consistent with other small sample size studies (Cuevas \& Fiore, 2014; Hurtley, 2017) the power analysis is not very high. Howard (2015) was able to use Cuevas and Fiore (2014) study of computer-based instructional strategy for his meta analyses of virtual reality applications. Even with a small sample size $(\mathrm{N}=46)$ post hoc power analysis yielded a power for the mean difference in Table 4 of only .1233, this study contributes to the literature investigating the impact of an EE-based constructivist science teaching approach as an effective instructional strategy.

\section{RECOMMENDATIONS FOR PRACTICE}

This study did find a significant statistical relationship in academic performance as measured on a standardized final exam. Even though this study did not find a significant statistical relationship in academic performance as measured on standardized unit tests, this study did not find a decrease in academic performance as measured on standardized unit tests.

In other words, the EE-based constructivist science teaching approach did help and did not hurt student performance. This study did find student perceptions of EE-based constructivist teaching approach to be generally positive, recommending the use of EE-based teaching approaches.

This study did find a significant statistical relationship in the development of environmental selfefficacy with the EE-based constructivist science teaching approach. Benefits seen in the literature promote scientific literacy and citizenship. Contextualized reform can foster an understanding of the nature of science and practical knowledge application (Hogan, 2002). Students taught with relevant experiences can develop higher environmental selfefficacy in making decisions that impact their daily lives. It is beneficial to our society to have citizens who are scientifically engaged (Hogan, 2002; Sadler, 2011). Using 
EE-based constructivist teaching approaches are recommended to increase scientific literacy and increase the STEM workforce.

\section{LIMITATIONS}

This study had limitations. The first limitation is that the researcher was one of the teachers in the study. Students could have responded to the environmental self-efficacy survey questions in ways they perceived the teacher wanted them to respond.

A second limitation of this study is the small sample size. Data were collected from physical science students from only one high school, of only two teachers. Over the course of the semester the sample size shrunk as some students' schedules changed and some students did not complete the unit tests or surveys. In the Unit 8 test, the traditional teaching approach group projected a significant negative difference. This was the only significant difference in Unit test data. With a small sample size, outliers can skew the data more easily.

With only two teachers in the study, teaching approach could be impacted by factors other than EEbased or traditional teaching. For example, one teacher was absent several days for family reasons. The traditional teaching approach teacher decided not to give the unit assessments for five of the 11 units citing that circumstances in the semester deemed the students ill-prepared to take the assessments. Students in the traditional teaching approach group averaged a higher pass rate for the course, perhaps because they were not tested on all of the course material, as well as a higher fail rate for the exam. Small sample size of teachers implementing the teaching approach is a third limitation of the study.

A fourth limitation of this study was how content knowledge was measured. Academic performance was limited to student performance on standardized tests. Standardized tests are one measure of content knowledge, and provide straight-forward quantitative data, but other measures might provide more insights into student performance on critical thinking and problem-solving skills. Studies such as Jones and Treeter (2003) posit that standardized tests are not a valid way to measure inquiry, constructivist lessons. In this study, the standardized tests were not consistent in their measurement of student achievement as students in the experimental group performed significantly higher on the standardized final exam but did not perform significantly higher on the standardized unit tests. Other measures of students' science knowledge might provide a different picture of student achievement and better insights into scientific literacy and the STEM pipeline.

In this study, EE themes provided the mechanism to promote student engagement and therefore scientific literacy. The impact of EE themes has been seen to bring relevancy to the lessons being taught (Lord, 1999; Wals et al., 2014) however, current political tensions could possibly decrease student engagement. The mention of "climate change" to some students might result in more motivation to understand issues in the news but other students might be turned off from the lesson thinking the topic is inappropriately exaggerated as "fake news." Varied perceptions of EE themes is a fifth limitation of the study.

This study investigated the use of the environment as the integrating context for learning science in a general approach. Research supported best practices have not been independently analyzed and reported. Specific EE themes have not been independently analyzed and reported. Student comments were generally positive but affinity for science was not measured pre and post intervention. Broad strokes is a sixth limitation of this study.

\section{RECOMMENDATIONS FOR FURTHER RESEARCH}

This study adds to the body of literature emerging in science education that encourages teaching science concepts around a central theme (Bybee, 2014). This study investigated the integration of science disciplinary core ideas with EE themes through constructivist teaching practices. More research is needed to more fully explore the impact. This study represents only two teachers in one semester of physical science instruction at one rural high school. Studies involving more teachers, more subjects and a greater variety of schools are needed.

Academic performance in this study was measured only with standardized tests. Other more contextualized or higher-level performance assessments (Austin \& Schmidt, 2010) might provide a better understanding of how EE-themes might impact classroom instruction. Longitudinal studies or broader scoped studies are needed.

This study measured environmental self-efficacy with the "hope" scale (Szczytko et al., 2018). Other instruments for measuring self-efficacy or other dispositions such as pro-environmental attitudes are needed. More research in how environmental selfefficacy might gage other forms of self-efficacy is needed.

This study found that students in classrooms with an EE-based constructivist teaching approach demonstrated enthusiasm and positive perceptions for learning. Studies and reviews including Lieberman (2013), Stevenson et al. (2013) and Hollweg et al. (2011) have found that EE builds problem solving skills, decreases behavior issues and increases student engagement. Designed journal or interview questions based on EE integration studies or constructivist classroom research studies could provide a more nuanced explanation of student perceptions. More 
research is needed to better describe how the EE themes impacted authentic learning opportunities. Furthermore, as this study integrates EE topics with teaching approach, unpacking the EE themes from the constructivist pedagogies is an area of future research.

\section{CONCLUSION}

This study investigated the integration of science disciplinary core ideas (Bybee, 2014) with EE themes through constructivist teaching practices. The impact on students' science achievement and environmental selfefficacy was measured through test and survey data. Students with an EE-based constructivist science teaching approach did perform better on science achievement tests than those with traditional science teaching. Students with an EE-based constructivist teaching approach developed higher environmental selfefficacy than their counterparts. Students who were in the EE-based constructivist teaching approach classroom tended to reflect on the activities by describing things that impacted them or what they thought about the things that impacted them. Students were generally positive about their perceptions. Integrating science disciplinary core ideas and environmental themes through constructivist teaching practices can meet the needs of increasing scientific literacy and increasing the number of students prepared for and entering STEM careers, a win-win for everyone.

\section{REFERENCES}

American Association for the Advancement of Science. (AAAS) (1993). Benchmarks for science literacy. New York: Oxford University Press.

Ardoin, N. M., Bowers, A. W., Roth, N. W., \& Holthuis, N. (2018). Environmental education and K-12 student outcomes: A review and analysis of research. The Journal of Environmental Education, 49(1), 1-17. https://doi.org/1 0.1080/00958964. 2017.1366155

Austin, B., \& Schmidt, N. (2010). Pedagogy, Environmental; Education, and Context: Promoting Knowledge Through Concept Mapping. In A. M. Bodzin, B. S. Klein \& S. Weaver (Eds.), The Inclusion of Environmental Education in Science Teacher Education. (pp. 225-236). Dordrecht; New York: Springer. Retrieved from http://www2. lib.ncsu.edu/catalog/record/NCSU2416664

Banet, E., \& Ayuso, G. E. (2003). Teaching of biological inheritance and evolution of living beings in secondary school. International Journal of Science Education, 25(3), 373-407.

Baviskar, S. N., Hartle, R. T., \& Whitney, T. (2009). Essential criteria to characterize constructivist teaching: Derived from a review of the literature and applied to five constructivist-teaching method articles. International Journal of Science Education, 31(4), 541-550.

Bodzin, A., Klein, B. S., \& Weaver, S. (2010). The inclusion of environmental education in science teacher education. Springer Science \& Business Media.

Banilower, E., Cohen, K., Pasley, J., \& Weiss, I. (2010). Effective science instruction: What does research tell us? Second edition. Portsmouth, NH: RMC Research Corporation, Center on Instruction.

Burrowes, P. A. (2003). A student-centered approach to teaching general biology that really works: Lord's constructivist model put to a test. The American Biology Teacher, 65(7), 491-502.

Bybee, R. W. (2014). NGSS and the next generation of science teachers. Journal of Science Teacher Education, 25(2), 211221. https:/ / doi.org/10.1007/s10972-0149381-4

Choi, J., \& Hannafin, M. (1995). Situated cognition and learning environments: Roles, structures, and implications for design. Educational Technology Research and Development, 43(2), 53-69. https://doi.org/10.1007/BF02300472

Cobern, W. W., Gibson, A. T., \& Underwood, S. A. (1995). Valuing science literacy. The Science Teacher, 62(9), 2831.

Cooper, J. L. (1995). Cooperative learning and critical thinking. Teaching of Psychology, 22(1), 7. Retrieved from https://proxying.lib.ncsu.edu/index.php? url=http:/ / search.ebscohost.com.prox.lib.ncsu.ed $\mathrm{u} /$ login.aspx?direct $=$ true\&db=a9h\&AN=95042009 $82 \&$ site $=$ ehost-live\&scope $=$ site

Cooper, L. Z. (2013). Student reflections on an LIS internship from a service learning perspective supporting multiple learning theories. Retrieved from https://proxying.lib.ncsu.edu/index.php? url=http:/ / search.ebscohost.com.prox.lib.ncsu.ed $\mathrm{u} /$ login. $\operatorname{asp} x$ ?direct $=$ true\& $\mathrm{db}=\mathrm{a} 9 \mathrm{~h} \& \mathrm{AN}=91546013$ \&site $=$ ehost-live\&scope $=$ site

Creswell, J. W. (2013). Research design: Qualitative, quantitative, and mixed methods approaches. Thousand Oaks, CA: Sage Publications.

Cuevas, H., \& Fiore, S. (2014). Enhancing learning outcomes in computer-based training via selfgenerated elaboration. Instructional Science, 42(6), 839-859.

DeBoer, G. E. (2000). Scientific literacy: Another look at its historical and contemporary meanings and its relationship to science education reform. Journal of Research in Science Teaching, 37(6), 582-601.

Dewey, J. (1938). Experience and education. New Your, NY: Kappa Delta Pi. English, L. D. (2016). STEM education K-12: perspectives on integration. International Journal of STEM Education, 3(3). https:/ / doi.org/10.1186/s40594-016-0036-1 
Glaze, A. (2018). Teaching and learning science in the 21st Century: Challenging critical assumptions in post-secondary science. Education Sciences, 8(1), 12. https:/ / doi.org/10.3390/educsci8010012

Greeno, J., \& Engestrom, Y. (2014). Learning in activity. In K. Sawyer (Ed). The Cambridge Handbook of The Learning Sciences (2nd ed.) (pp. 128-147). Cambridge, UK: Cambridge University Press.

Hogan, K. (2002). Pitfalls of community-based learning: How power dynamics limit adolescents' trajectories of growth and participation. Teachers College Record, 104(3), 586. Retrieved from https:/ / proxying.lib.ncsu.edu/index.php?url=htt p:/ / search.ebscohost.com.prox.lib.ncsu.edu/login .aspx?direct $=$ true $\& \mathrm{db}=\mathrm{a} 9 \mathrm{~h} \& \mathrm{AN}=6280860 \&$ site $=\mathrm{eh}$ ost-live\&scope $=$ site

Hollweg, K. S., Taylor, J., Bybee, R. W., Marcinkowski, T. J., McBeth, W. C., \& Zoido, P. (2011). Developing a framework for assessing environmental literacy. Environmental Education. Washington, DC: NAAEE. http:/ / www.naaee.net

Howard, M. (2015). Science fiction meets scientific inquiry: A task-technology fit/computer-based training framework and a meta-analysis of virtual reality applications for intervention, training, and therapy purposes - ProQuest Retrieved from https:/ / search-proquest-com.prox.lib.ncsu.edu/ education/docview/2101890555/4A8000EC15FE4 A13PQ/6? accountid $=12725$

Hungerford, H. R., \& Volk, T. L. (1990). Changing learner behavior through environmental education. Journal of Environmental Education, 21(3), 8-21.

Hurley, T. V. (2017). Experiential teaching increases medication calculation accuracy among baccalaureate nursing students. Nursing Education Perspectives, 38(1), 3436.

Iamarino, D. L. (2014). The benefits of standards-based grading: A critical evaluation of modern grading practices. Current Issues in Education, 17(2). Retrieved from https:/ / cie.asu.edu/ojs/index.php / cieatasu/article/view/1234

Johnson, C. C., Peters-Burton, E. E., \& Moore, T. J. (Eds.). (2016). STEM road map: A framework for integrated STEM education. New York, NY: Routledge.

Lave, J., \& Wenger, E. (1991). Situated learning: Legitimate peripheral participation. New York, NY: Cambridge University Press.

Lee, E. A., \& Brown, M. J. (2018). Connecting inquiry and values in science education. Science $\mathcal{E}$ Education, 27(12), 63-79.

Lieberman, G. A., \& Hoody, L. L. (1998). Closing the achievement gap: Using the environment as an integrating context for learning. San Diego, CA.

Lieberman, G. A. (2013). Education and the Environment: Creating Standards-Based Programs in Schools and
Districts(SEER). Harvard Education Press. 8 Story Street First Floor, Cambridge, MA. http:/ / www.seer.org/pages/eic.html

Lord, T. R. (1999). A comparison between traditional and constructivist teaching in environmental science. The Journal of Environmental Education, 30(3), 22-27.

National Research Council. (NRC) (1996). National science education standards. National Committee on Science Education Standards and Assessment, Center for Science, Mathematics, and Engineering Education. Washington, DC: National Academy Press.

National Research Council. (NRC) (2000). How people learn: Brain, mind, experience, and school: Expanded Edition. Committee on Developments in the Science of Learning and Committee on Learning Research and Educational Practice, Commission on Behavioral and Social Sciences and Education. Washington, DC: National Academy Press.

National Research Council. (NRC) (2005). How Students Learn: History, Mathematics, and Science in the Classroom. Committee on How People Learn, A Targeted Report for Teachers, M. S. Donovan \& J. D. Bransford, Editors. Division of Behavioral and Social Sciences and Education. Washington, DC: The National Academies Press.

North American Association for Environmental Education. (NAAEE) (2009). Excellence in Environmental Education: Guidelines for Learning (K12). Northern Illinois University: National Project for Excellence in Environmental Education.

Österlind, K. (2005). Concept formation in environmental education: 14-year olds' work on the intensified greenhouse effect and the depletion of the ozone layer. International Journal of Science Education, 27(8), 891-908.

Patton, M. Q. (2015). Qualitative research $\mathcal{E}$ evaluation methods: Integrating theory and practice ( $4^{\text {th }}$ ed.). Thousand Oaks, CA: SAGE Publications, Inc.

Plakitsi, K. (2010). Collective curriculum design as a tool for rethinking scientific literacy. Cultural Studies of Science Education, 5(3), 577-590. https:/ / doi.org/10.1007/s11422010-9288-0

Roberts, D. A., \& Bybee, R. W. (2014) Scientific literacy, science literacy, and science education. In N. G. Lederman \& S. K. Abell (Eds.), Handbook of research on science education, volume II (pp 545-558). New York: Routledge. Retrieved from https:/ / proxying. lib.ncsu.edu/index.php?url=http:/ / search.ebscoh ost.com.prox.lib.ncsu.edu/login.aspx?direct=true $\& \mathrm{db}=$ nlebk\&AN=812733\&site=ehost-live

Sadler, T. D. (2011). Situating socio-scientific issues in classrooms as a means of achieving goals of science education. In Socio-scientific Issues in the Classroom (pp. 1-9). Springer, Dordrecht. 
Stevenson, K. T., Peterson, M. N., Bondell, H. D., Mertig, A. G., \& Moore, S. E. (2013). Environmental, Institutional, and Demographic Predictors of Environmental Literacy among Middle School Children. PLoS ONE 8(3). https://doi.org/10.1371/journal.pone.0059519

Szczytko, R., Stevenson, K., Peterson, M. N., Nietfeld, J., \& Strnad, R. L. (2019). Development and validation of the environmental literacy instrument for adolescents. Environmental Education Research, 25(2), 193-210. https://doi.org/10.1080/13504622. 2018.1487035

Tretter, T. R., \& Jones, M. G. (2003). Relationships between inquiry-based teaching and physical science standardized test scores. School Science and Mathematics, 103(7), 345-350.

UNESCO, U. (1977). The Tbilisi declaration. In Intergovernmental Conference on Environmental Education (pp. 14-26).

US News (2017, July 18). Clayton High School. Retrieved from https://www.usnews.com/education/besthighschools/north-carolina/

Volk, T. L., Hungerford, H. R., \& Tomera, A. N. (1984). A national survey of curriculum needs as perceived by professional environmental educators. The Journal of Environmental Education, 16(1), 10-19.
Vygotsky, L. S. (1978). Mind in society: The development of higher psychological processes. Harvard University Press.

Wals, A. E., Brody, M., Dillon, J., \& Stevenson, R. B. (2014). Convergence between science and environmental education. Science, 344(6184), 583584.

Wang, H., Hong, Z., Liu, S., \& Lin, H. (2018). The impact of socio-scientific issue discussions on student environmentalism. Eurasia Journal of Mathematics, Science and Technology Education, 14(12), em1624. https:/ / doi.org/10.29333/ejmste/95134

Windschitl, M. (2002). Framing constructivism in practice as the negotiation of dilemmas: An analysis of the conceptual, pedagogical, cultural, and political challenges facing teachers. Review of Educational Research, 72(2), 131-175.

Wilcox, J. (2011). Holding ourselves to a higher standard: Using standards-based grading in science as a means to improve teaching and learning. Iowa Science Teachers Journal, 38(3), 4-11.

Wolcott, H. F. (1994) Transforming qualitative data: Description, analysis, and interpretation. Thousand Oaks, CA: Sage. 


\section{APPENDIX A}

\section{Self-efficacy or "hope" scalew}

Self-efficacy or "hope" scale

Please circle the answer that best describes how you feel about the following statements. There is no right or wrong answer.

strongly disagree (1), disagree (2), neutral (3), agree (4), strongly agree (5)

I believe people will be able to solve most environmental problems.

The actions I can take are too small to help solve most environmental problems.*

I believe scientists will be able to find ways to solve environmental problems.

Even when some people give up, I know there will be people who will continue to try to solve environmental problems.

Environmental problems are out of my control.*

Because people can learn from our mistakes, we will influence the environment in a positive direction.

Every day, more people care about environmental problems.

If everyone works together, we can solve environmental problems.

At the present time, I am energetically pursuing ways to solve environmental problems.

Environmental problems are so complex, we will never be able to solve them.*

I know that there are many things that I can do to help solve environmental problems.

I feel helpless to solve environmental problems.*

*Reverse questions were reverse scaled.

\section{http://www.ejmste.com}

